\title{
Education Quality Process Model and Its Influence on Students' Perceived Service Quality
}

\author{
Choon Ling Kwek (Corresponding author) \\ Faculty of Management and Information Technology, UCSI University \\ 1, Jalan Menara Gading, UCSI Heights, 56000 Kuala Lumpur, Malaysia \\ Tel: 6-016-6886-248Ｅ-mail:kwekcl@ucsi.edu.my
}

Teck Chai Lau

Faculty of Accountancy and Management, Universiti Tunku Abdul Rahman

Lot PT21144, Jalan Sungai Long, Bandar Sungai Long, Cheras, 43000 Kajang, Selangor, Malaysia

Tel: 6-016-3917-683 E-mail: lautc@utar.edu.my

Hoi Piew Tan

Faculty of Accountancy and Management, Universiti Tunku Abdul Rahman

Lot PT21144, Jalan Sungai Long, Bandar Sungai Long, Cheras, 43000 Kajang, Selangor, Malaysia

Tel: 6-016-2862-719_E-mail: hptan@utar.edu.my

\begin{abstract}
Service quality has become an important topic in the services marketing literature because it affects the cost, profitability, customer satisfaction, and customer retention (Buzzell \& Gale, cited in Buttle, 1996; Bolton \& Drew, 1991; Reichheld \& Sasser, 1990). As such, it is crucial to identify the determinants of the students' perceived service quality in higher education. The aim of this research is to investigate the determinants of students' perceived service quality for a private higher education institution in Malaysia, based on the process model of education quality. A total of 458 undergraduate business students from a private university in Malaysia participated in this research. The research found that quality of librarians, staff responsiveness from the Division of Examinations and Awards, curriculum, amount of recreational activities, and the process model of education quality are positively related to the students' perceived service quality.
\end{abstract}

Keywords: Education quality, Process model, Perceived service quality, Malaysia

\section{Introduction}

Students' retention and their academic performance are influenced by the service quality provided by the higher education institutions (Sander, Stevenson, King and Coates, 2000). Intensive competition in the higher education sector (Ford, Joseph and Joseph, 1999), internationalization of higher education (Marzo-Navarro, Pedraja-Iglesias and Rivera-Torres, 2005), and the classification of education as a marketable service (Cuthbert, 1996; Mazarrol, 1998) have prompted the management of the various public and private higher education institutions to pay more attention in assessing the overall students' perceived service quality. Due to the important role of the students' perceived service quality in determining the students' retention and their academic performance in the respective higher education institutions, there is a need to identify what are the determinants for the overall students' perceived service quality.

There are both public and private higher education institutions in Malaysia. Eighteen publicly funded higher education institutions have been set up by the government to provide tertiary education opportunities to the nation (Ministry of Higher Education, 2006). In the privately-funded higher educational sector, a total of 22 private universities and university colleges, 4 foreign university branch campuses and 532 private colleges are competing aggressively to enroll 341,310 Malaysian and foreign students in their various programmes offered by these higher education institutions in the country in year 2005 (Education Guide Malaysia, 2006). The proliferation of offering local completion overseas degree programme as well as the establishment of the various private universities and university colleges in Malaysia have drawn the management's attention from those 
private higher education institutions to explore and evaluate the determinants of students' service quality based on different education quality models. The aim of this research is to investigate the determinants of students' perceived service quality for a private higher education institution in Malaysia, based on the process model of education quality.

\section{Literature Review}

\subsection{Education Quality}

The concept of quality is not well defined in higher education (Cheng and Tam, 1997; Pounder, 1999). According to Mukhopadhyay (cited in Sahney, Banwet and Karunes, 2004, p.149), the term "quality in education' has been defined by various scholars, such as "excellence in education" (Peters and Waterman, 1982), "value addition in education" (Feigenbaum, 1951), "fitness of educational outcome and experience for use" (Juran and Gryna, 1988), "specifications and requirements" (Gilmore, 1974; Crosby, 1979), "defect avoidance in education process" (Crosby, 1979) and "meeting or exceeding customer's expectations of education" (Parasuraman, Zeithaml and Berry, 1985). Therefore, a single definition of education quality is not possible, rather, it would be more appropriate to define education quality based on the criteria that stakeholders used to judge quality, and also to consider the competing views when assessing the education quality (Green, cited in Sahney et al., 2004). The following section discusses the concept of education quality and different models of education quality.

Cheng (cited in Cheng and Tam, 1997, p.23) defines education quality as "the character of the set of elements in the input, process, and output of the education system that provides services that completely satisfy both internal and external strategic constituencies by meeting their explicit and implicit expectations". The seven models of education quality proposed by Cheng and Tam (1997) to evaluate the concept of education quality are: (1) goal and specification model; (2) resource-input model; (3) process model; (4) satisfaction model; (5) legitimacy model; (6) absence of problems model; and (7) organizational learning model. Each of the education quality models has its own particular characteristics, strengths and limitations that describe the aspects of the education quality in its own respective ways and yet they are interlinked with one another (Tam and Cheng, 1996). These models allow the administrators of the tertiary institution to assess their own education quality (Tam and Cheng, 1996).

Advocacy for the process model asserts that education quality can be enhanced if the education institution can smooth the internal process and subsequently provide fruitful learning experiences to the relevant stakeholders (Cheng and Tam, 1997). The process model of education quality is very relevant to the management of higher education institution when there is a clear relationship between process and educational outcomes. Examples of the indicators for quality evaluation in the process model of education quality include leadership, participation, social interactions, classroom climate, learning activities and experiences.

Only one out of the seven models of education quality proposed by Cheng and Tam (1997) will be adopted in this research to develop the conceptual framework and test the hypotheses because the tertiary institution may be unable to achieve total education quality by adopting all the seven models at the same time due to the constrain in resources and capabilities (Tam and Cheng, 1996). The selected model of education quality is process model of education quality.

\subsection{Process Model of Education Quality}

The process model of education quality assumes that "smooth and healthy internal processes and fruitful learning experiences" will determine the quality of output and achievement of goals (Tam and Cheng, 1996, p.20). This model also suggests that with a smooth internal institutional process, lecturers will be able to deliver their teaching more effectively to enable students to absorb the learning process better (Cheng and Tam, 1997). Experience in process is regarded as one of the educational aims and outcomes (Cheng and Tam, 1997). Therefore, all the important internal activities or practices that have taken place in the education institution can be classified as indicators of education quality for process model, including "leadership, communication channels, participation, co-ordination, adaptability, planning, decision making, social interactions, social climate, teaching methods, classroom management, learning strategies, and learning experiences" (Cheng and Tam, 1997, p.26). In short, all these indicators of education quality can be classified into three categories known as management process, teaching process, and learning process (Cheng, 2003). The education quality indicators that have been identified for the process model in this research are: (1) quality of librarians; (2) staff responsiveness from the Division of Examinations \& Awards; (3) curriculum; and (4) amount of recreational activities. These four indicators will be tested as independent variables under the grouping of the process model. 
Although Tam and Cheng (1996) argue that the process model of education quality can be adopted by the administrators of the tertiary institution to evaluate perceived service quality, there is a lack of empirical testing in the extant literature to support this argument. Due to the lacking of extant literature in explaining the relationship between the process model of education quality and the students' perceived service quality, thus this has created a hypothesized gap to test this relationship in this study.

\subsection{Service Quality and Perceived Service Quality}

There are eight dimensions of quality that comprise of performance, features, reliability, conformance, durability, serviceability, aesthetics and perceived quality (Garvin, 1987). The perceived service quality fully explains the quality dimension in the services industry (Reeves and Bednar, 1994) and this statement is supported by Kang and James (2004) who assert that perceived service quality is the core issue of service quality in the services marketing literature.

Service quality is defined as "the difference between customers' expectations for service performance prior to the service encounter and their perceptions of the service perceived" (Asubonteng, McCleary and Swan, 1996, p.64). While the perceived service quality is defined as "a global judgment, or attitude, relating to the superiority of the service" (Parasuraman, Zeithaml and Berry, 1988, p.16), the core concept of service quality is the disconfirmation of expectations theory (Dawes and Rowley, 1999). According to the disconfirmation of expectations theory, the comparison of the expectations and perceptions of services will generate the decision of disconfirmation (Ruyter, Bloemer and Peeters, 1997) and subsequently this disconfirmation affects the perceived service quality (Gotlieb, Grewal and Brown, 1994; Philip and Hazlett, 1997). Customers form positive disconfirmation when the performance of the services offered by the service provider exceeds their prior expectations. Whereas, customers will form negative disconfirmation when prior expectations exceed the performances of the services that offered by the service providers (Ruyter et al., 1997). Negative disconfirmation of expectations will create negative impacts to the perceived quality of the services offered (Gotlieb et al., 1994). This relationship is supported both theoretically (Fishbein and Ajzen, cited in Gotlieb et al., 1994) and empirically (Brown and Sawartz, Parasuraman, et. al., both cited in Gotlieb et al., 1994) in the extant literature.

Among the various service quality models, the Technical and Functional Quality Model (Gronroos, 1984) and the Service Quality Gap Model, also known as SERVQUAL model (Parasuraman et al., 1985) are the two most commonly quoted service quality models. There are five key dimensions of the SERVQUAL model in which can be used by consumers to evaluate perception of the perceived service quality. These dimensions include reliability, assurance, tangibles, responsiveness and empathy (Parasuraman et al., 1988).

The SERVQUAL model is frequently used and adopted in the extant literature to evaluate the students' perceived service quality in the education industry (Russell, 2005). The SERVQUAL model that is developed by Parasuraman et al. (1985) is adapted in this research to measure "the gap between customers' expected level of service and their perceptions of the actual service perceived" (Bennett, Bove, Dann, Drennan, Frazer, Gabbott, Hill, Lawley, Matear, Perry, Sparks, Summers, Sweeney, Ward and White, 2003, p.84). However, there is no consensus in the extant literature pertaining to the development and definition of the determinants of the students' perceived service quality in higher education.

In combining the studies of the various determinants of the overall students' perceived service quality and the adoption of the process model of education quality, four independent variables for the students' perceived service quality have been developed in this research: (1) quality of librarians; (2) staff responsiveness from the Division of Examinations \& Awards; (3) curriculum; and (4) amount of recreational activities.

\subsubsection{Quality of Librarians}

The human interaction component will affect the customer's evaluation process in evaluating the perceived service quality (Bitner, Booms and Tetreault. 1990). The quality of librarians in the extant literature has been tested as one of the dimensions that determine the customers' evaluation of service quality in academic libraries (Nagata, Satoh, Gerrard and Kytomaki, 2004). Library services had been theoretically quoted as one of the determinants of the students' perceived service quality (Athiyaman, 1997; Hill, 1995). In other words, quality of librarians is speculated or implied as one of the determinants of the students' perceived service quality.

Nagata et al. (2004) assert that the quality of librarians should include the ability of librarians to deal with students in a concerned or considerate fashion, the reliability and consistency as well as dependability of librarians in handling students' service problems, the readiness of the librarians in responding to students' questions, the competency of librarians in answering students' questions, and finally the efforts of librarians in understanding the needs of students. These items that were developed based on the 'inside-out' approach are 
tested in this research to determine the impact of the quality of librarians towards the students' perceived service quality.

\subsubsection{Staff Responsiveness from the Division of Examinations \& Awards}

Responsiveness is defined as the willingness of the service provider to help customers and to provide prompt services (Parasuraman et al., 1985, 1988). Responsiveness as one of the five dimensions of the SERVQUAL model, affects the perceived service quality (Parasuraman et al., 1985, 1988). Responsiveness has been tested by many researchers in the extant literature as one of the important determinants of the students' perceived service quality (Soutar and McNeil, 1996; Cuthbert, 1996; Pariseau and McDaniel, 1997; LeBlanc and Nguyen, 1997; Ham and Hayduk, 2003; Sohail and Shaikh, 2004). Staff responsiveness in this research will be limited to the staff from the Division of Examinations \& Awards in a particular university setting. The items in the staff's responsiveness from the Division of Examinations \& Awards are adopted from LeBlanc and Nguyen (1997) include if the students are informed promptly of any changes by the staff, if the examination registration is timely and error free, and finally if the examination records are kept accurately by the staff. These items that were developed based on the 'inside-out' approach are tested in this research to determine the impact of the staff responsiveness from the Division of Examinations \& Awards towards the students' perceived service quality.

\subsubsection{Curriculum}

Teaching is one of the important factors in determining the students' perceived service quality while course content is one of the teaching components (Hill, 1995). Course content is also known as curriculum. Curriculum has been tested by many researchers in the extant literature as one of the important determinants of the overall students' perceived service quality (Athiyaman, 1997; LeBlanc and Nguyen, 1997; Sohail and Shaikh, 2004).

According to LeBlanc and Nguyen (1997), curriculum refers to the suitability of the academic programmes and course content, the number of courses offered, and finally the extent to which the objectives of the academic programmes are explained to the students. These items that were developed based on the 'inside-out' approach will be tested in this research to determine the impact of the curriculum towards the students' perceived service quality.

\subsubsection{Amount of Recreational Activities}

Recreational activities have been tested by some researchers in the extant literature as one of the important determinants of the students' perceived service quality for the higher education institution. (Athiyaman, 1997; Ford et al., 1999; and Joseph, Yakhou and Stone, 2005). The amount of recreational activities includes opportunities to participate in a variety of sports, offering of sports teams for entertainment, student organizations are offered as extra-curricular activities, extra-curricular activities are offered to students, and finally recreational facilities and programmes are offered to students (Joseph et al., 2005). These items that were developed based on the 'outside-in' approach (Joseph et al., 2005) are tested in this research to determine the impact of the amount of the recreational activities towards the students' perceived service quality.

\section{4 "Outside-in" Approach and "Inside-out" Approach}

In the extant literature, there are two approaches adopted by researchers in setting the determinants of the students' perceived service quality in higher education. Service quality standards can be evaluated based on the perspective of the customers ('outside-in' approach) or the perspective of the service providers ('inside-out' approach) (Hoffman and Bateson, 2006). The 'inside-out' approach is where the university's academicians and administrators will be setting the determinants of the students' perceived service quality. They assume that they know the students' needs as well as the lecturers' contribution (Sander et al., 2000, p.309). LeBlanc and Nguyen (1997), Nagata et al. (2004) and Sohail and Shaikh (2004) are some of the proponents who prefer to adopt the 'inside-out' approach in evaluating the students' perceived service quality in higher education. However, 'inside-out' approach leads to the poor performance in service quality because feedback from the students was not taken into consideration (Joseph et al., 2005). Joseph et al. (2005, p.67) argue that "if firms do not know what their own customers desire in terms of service, then how can they possibly design programmes that match customer expectations of what constitute good service". While the key proponents who prefer to adopt the 'outside-in' approach in evaluating the students' perceived service quality in the higher education are Joseph et al. (2005).

The 'outside-in' approach is where the determinants of the overall students' perceived service quality are determined based on the feedback from the students and outside consultants (Joseph et al., 2005). Researchers who have adopted the 'outside-in' approach would "research what customers expect of the service and they then work to provide the service that meets those customer expectations" (Zeithaml, Parasuraman and Berry, cited in 
Sander et al., 2000, p.309). A combination of determinants of the students' perceived service quality that derived from both the 'inside-out' and 'outside-in' approaches provide a full picture for the administrators of the higher education institutions to understand the students' perceived service quality based on the opinions and feedback from the academics and students. Three determinants such as 'quality of librarians', 'staff responsiveness from the Division of Examinations \& Awards', and 'curriculum' have adopted 'inside-out' approach to evaluate students' perceived service quality (Nagata et al., 2004; LeBlanc and Nguyen, 1997); determinant such as 'amount of recreational activities' has adopted 'outside-in' approach to evaluate students' perceived service quality (Joseph et al., 2005).

\subsection{Hypotheses}

Prior discussion has led to a brief examination of the extant literature and the resultant research gaps led to the development of the hypotheses in this research. The five hypotheses are:

$\mathrm{H}_{1}$ : The quality of librarians is positively related to the students' perceived service quality.

$\mathrm{H}_{2}$ : There is a positive relationship between the staff responsiveness from the Division of Examinations \& Awards and the students' perceived service quality.

$\mathrm{H}_{3}$ : The curriculum is positively related to the students' perceived service quality.

$\mathrm{H}_{4}$ : There is a positive significant relationship between the amount of recreational activities and the students' perceived service quality.

$\mathrm{H}_{5}$ : There is a positive relationship between the process model of education quality and the students' perceived service quality.

\section{Research Method}

\subsection{Research Design}

Positivism approach was adopted in this research because this approach: (1) allowed the researcher to search for truths of the observation by empirical evidence via the hypothetico-deductive method; and (2) many researches and observations on the students' perceived service quality had been conducted and the extant literature was well developed (Jankowicz, 2005). The collection of primary data was used as opposed to secondary data because the secondary data is unable to serve the objectives of this research.

\subsection{Questionnaire Design}

The questionnaire is divided into three parts in this research. The first part of the questionnaire provides general information as to who are eligible to take part in this survey. The second part of the questionnaire elaborates the independent variables and dependent variable that would be tested in the survey. The third part of the questionnaire identifies the personal information of the respondents. Questionnaire in the form of scaled-response questions was adopted in the second part of the questionnaire because "scaling permits measurement of the intensity of respondents' answers" (Churchill and Brown, 2004, p.329). The items of the questionnaire in this research were adopted from different sources of the extant literature. The items for the independent variable "quality of librarians" were adopted from Nagata et al. (2004). Both independent variables "staff responsiveness from the Division of Examinations \& Awards" and "curriculum" were adopted from LeBlanc and Nguyen (1997). The items for independent variable "amount of recreational activities" were adapted from Joseph et al. (2005). Lastly, the items for dependent variable "students' perceived service quality" are adopted from Lee, Lee and Yoo (2000). Interval scale was adopted for the measurement scales in this research because the scale allowed "the comparison of the size of the differences among and between members" (Churchill and Brown, 2004, p.324). Likert scale format was applied in this research because the scale was suitable for self-administered survey method (Hair, Bush and Ortinau, 2004). A 7-point Likert scale anchored by "much less than expected" (1) to "much better than expected" (7) was adopted as the attitude measurement for independent variables (adopted from LeBlanc and Nguyen, 1997). Three types of 7-point Likert scale anchored by "very low" (1) to "very high" (7), "poor" (1) to "excellent" (7), and "unlikable" (1) to "likable" (7) were adopted as the attitude measurement for dependent variable (adopted from Lee et al, 2000).

\subsection{Sampling and Administration of Survey}

The target population in this research covered all the undergraduate students enrolled in University ' $A$ ' and the sampling unit included all the current full-time undergraduate business students in University 'A'. Students who had completed at least one semester in University ' $A$ ' were targeted for this study because they are familiar with the business school faculty and services in comparison with those newly enrolled students. The sample size was 500 and convenience-sampling technique was used to select potential respondents in this survey. 
Self-administered survey method in the form of drop-off surveys technique was adopted in this research to ensure the confidentiality and non-obligation aspects of participating in the survey. Questionnaire survey would be conducted in University "A" and this survey was conducted in the lecture hall where respondents could return the questionnaires into the box allocated in the lecture hall. The voluntary nature of the participation was explained verbally as well as being indicated in the survey questionnaire. Potential student participants were invited to complete an anonymous survey questionnaire that would take approximately 15 minutes of the student respondent's time.

\section{Research Results}

A total of 500 sets of questionnaires were distributed to the potential student respondents in the lecture hall and a total of 479 questionnaires were collected. Out of that, 21 sets of questionnaires were considered unusable because they were incomplete whereby over 25 percent of the questions in Part Two of the questionnaire were not answered (Sekaran, 2003). It was assumed that the respondents were either unwilling to cooperate or not serious with the survey. Therefore, only 458 usable sets of collected questionnaires were used for the data analysis. In conclusion, the response rate was 91.60 percent.

\subsection{Respondents' Demographic Profile}

Based on the survey, the male respondents represented 32.5 percent of the total respondents while the female respondents represented 67.5 percent of the total respondents. This is a normal phenomenon because most of the tertiary students in Malaysia are female. The age distributions of the respondents were: (1) between the age of 20-22 years old ( 83.2 percent); (2) less than 20 years old ( 10 percent); (3) between $23-25$ years old ( 6.3 percent); (4) over 28 years old ( 0.4 percent); and (5) between $26-28$ years old ( 0 percent). In terms of the ethnic groups based on this research, the races were distributed to the majority of Chinese ( 84.5 percent), Malay (10 percent), other races ( 0.7 percent), and Indian (4.6 percent). The respondents were skewed to the Chinese ethnic group because the survey was conducted in a private higher education institution, not in a public higher education institution. Based on the categories of current years of study, the distribution of the respondents was fairly spread across the current years of study. The categories of the current years of study of the total respondents consist of 30 percent currently enrolled in year one, 40 percent currently enrolled in year two and 30 percent currently enrolled in year three.

\subsection{Reliability Test}

The reliability of a measure indicates the stability and consistency with which the instrument measures the concept and helps to assess the 'goodness' of a measure (Cavana, Delahaye and Sekaran, 2001). All the constructs were tested for the consistency reliability of the items within the constructs by using Cronbach's alpha. Based on Table 1, the results indicated that the Cronbach's alpha for all the five constructs were well above 0.7 as recommended by Cavana et al. (2001). Cronbach's alpha for the constructs ranged from the lowest of 0.841 (staff responsiveness from the Division of Examinations \& Awards) to 0.932 (quality of librarians). In conclusion, the results showed that the scores of the Cronbach's alpha for all the constructs used in this research exceeded the preferable scores of 0.70 and they indicated that the measurement scales of the constructs were stable and consistent in measuring the constructs.

\subsection{Validity Test}

According to Hair, Babin, Money and Samouel (2003, p.174), "validity is the extent to which a construct measures what it is supposed to measure". Construct validity was adopted in this research as validity measurement and factor analysis was used to measure the construct validity (Cavana et al., 2001). The details of the factor analysis were presented in Table 1 .

The factor analysis was appropriate because the value of Kaiser-Meyer-Olkin (KMO) was 0.878 (between 0.5 and 1.0) and the statistical test for Bartlett test of sphericity was significant $(\mathrm{p}=0.000$; d.f. $=171)$ for all the correlations within a correlation matrix (at least for some of the constructs). Based on the principal components analysis and VARIMAX procedure in orthogonal rotation that were adopted in the factor analysis, the results showed that the Eigenvalues for all the constructs were greater than 1.0, ranging from the lowest of 1.155 (staff responsiveness from the Division of Examinations \& Awards) to the highest of 7.031 (quality of librarians). In term of convergent validity, the factor loadings for all items within a construct were more than 0.50 . Discriminant validity indicated that all items were allocated according to the different constructs. Therefore, the items were not overlapping and they supported respective constructs.

\subsection{Regression Analysis}

\subsubsection{Multiple Regression Analysis}


Multiple regression analysis is defined as "a statistical technique which analyzes the linear relationships between a dependent variable and multiple independent variables by estimating coefficients for the equation for a straight line" (Hair et al., 2004, p.578). Multiple regression analysis was carried out to test the hypotheses that were identified. The results of the multiple regression analysis are presented in Table 2.

The $p$ value of the t-test $(p=0.000)$ for the quality of librarians is less than the alpha value of 0.05 . Therefore, the research study concludes that the quality of librarians is positively related to the students' perceived service quality. According to Bitner et al. (1990), human interaction component will affect the customer's evaluation process in evaluating the perceived service quality. In the extant literature, quality of librarians had been tested as one of the dimensions that determine the customers' evaluation of service quality in academic libraries (Nagata et al., 2004). Library services had been theoretically quoted as one of the determinants of the students' perceived service quality (Athiyaman, 1997; Hill, 1995). In other words, quality of librarians is speculated or implied as one of the determinants of the students' perceived service quality. The finding of this research suggests that quality of librarians is positively related to the students' perceived service quality. Thus, the findings add new knowledge to the extant literature.

Based on Table 2, the $p$ value of the t-test $(p=0.000)$ for staff responsiveness is less than the alpha value of 0.05 . Therefore, the research study concludes that the staff responsiveness from the Division of Examinations \& Awards is positively related to the students' perceived service quality. The extant literature suggests that staff responsiveness from higher education institutions will affect the students' perceived service quality towards the enrolled higher education institution (Soutar and McNeil, 1996; Cuthbert, 1996; Pariseau and McDaniel, 1997; LeBlanc and Nguyen, 1997; Ham and Hayduk, 2003; Sohail and Shaikh, 2004). Thus, the findings from the current study support the extant literature.

The $\mathrm{p}$ value of the t-test $(\mathrm{p}=0.000)$ for curriculum is less than the alpha value of 0.05 . Therefore curriculum is positively related to the students' perceived service quality. The extant literature suggests that curriculum will affect the students' perceived service quality towards the higher education institution enrolled (Athiyaman, 1997; LeBlanc and Nguyen, 1997; Sohail and Shaikh, 2004). Thus, the findings support the extant literature.

Finally, the study concludes that the amount of recreational activities is positively related to the students' perceived service quality. This is based on the result of the $p$ value of the t-test $(p=0.000)$ is less than the alpha value of 0.05 . The extant literature suggests that the amount of recreational activities will affect the students' perceived service quality towards the higher education institution enrolled (Athiyaman, 1997; Ford et al., 1999; and Joseph et al., 2005), which is supported in this study.

The following multiple regression equation was formed:

\section{Overall Students' Perceived Service Quality}

$=\mathbf{2 . 6 8 3}+\mathbf{0 . 2 1 3}$ Curriculum $+\mathbf{0 . 1 0 7}$ Amount of Recreational Activities $+\mathbf{0 . 2 1 1}$ Staff Responsiveness from the
Division of Examinations \& Awards $+\mathbf{0 . 1 1 2}$ Quality of Librarians

The values of un-standardized Beta coefficient among the independent variables tested in the hypotheses ranged from the weakest relationship of 0.107 (between the amount of recreational activities and the students' perceived service quality) to the strongest relationship of 0.213 (between the curriculum and the students' perceived service quality). It may conclude that the "curriculum" is the most important antecedent in affecting the students' perceived service quality. "Staff responsiveness from the Division of Examinations \& Awards" (0.211) and "quality of librarians" (0.112) are ranked the second and third most important of antecedents to the students' perceived service quality. The change of the students' perceived service quality is explained 30.9 percent by a combination of various independent variables ( $\mathrm{r}$ square $=0.309$ ), including quality of librarians, staff responsiveness from the Division of Examinations \& Awards, curriculum and amount of recreational activities.

\subsubsection{Simple Regression Analysis}

A simple regression analysis was conducted to test the fifth hypothesis. The simple regression "is a procedure for deriving a mathematical relationship in the form of an equation, between a single metric dependent or criterion variable and a single metric independent or predictor variable" (Hair, Black, Babin, Anderson and Tatham, 2006; Malhotra, Hall, Shaw and Oppenheim, 2006, p.692). The objective of adopting the simple regression "is to find an independent variable that will improve on the baseline prediction" (Hair et al., 2006, p.178). The result of simple regression analysis is presented in Table 3 .

The composite reliability for the process model of education quality is 0.603 . Thus, the internal consistency reliability of the measures (that is the quality of librarians, staff responsiveness from the Division of Examinations \& Awards, curriculum, and amount of recreational activities to measure the process model of 
education quality) in this study can be considered moderate (Hair et al., 2003). The $p$ value of the t-test ( $p=$ 0.000 ) is less than the alpha value of 0.05 . Therefore, the study concludes that the process model of education quality is positively related to the students' perceived service quality. Due to the lack of empirical testing in the extant literature to explain the relationship between the process model of education quality and the students' perceived service quality, the research finding in this study has contributed and advanced the extant literature.

The following simple regression equation was formed:

\section{Overall Students' Perceived Service Quality}

\section{$=$ 3.224 + 0.142 Process Model of Education Quality}

The simple regression equation indicates that the process model of education quality is the antecedent of the students' perceived service quality. The change of the students' perceived service quality is explained 29.8 percent by the process model of education quality ( $\mathrm{r}$ square $=0.298)$.

\section{Conclusion}

\subsection{Implications of the Research}

The research findings and contributions have brought some implications to various stakeholders. The implications can be divided into two different categories: theoretical implication and managerial implication.

There are two theoretical implications in this research. Based on the extant literature, most of the researchers either use the 'inside-out' or 'outside-in' approach to evaluate the students' perceived service quality. It is discovered in the research findings that the formation of determinants based on the combination of both the 'inside-out' and 'outside-in' approaches could be used concurrently by researchers to evaluate the students' perceived service quality. In addition, the research finding in this research offer empirical testing to support the antecedent relationship between the process model of education quality and the students' perceived service quality. This research finding has contributed and advanced the extant literature.

In term of managerial implication, the research findings do provide some insights and feedback for the administrators of the higher education institutions in drafting various managerial strategies on how to increase the level of the students' perceived service quality. The administrators should adopt an integrated approach (by combining the 'inside-out and 'outside-in' approaches) to develop determinants in the process of evaluating the students' perceived service quality. In addition, administrators should not isolate the models of education quality and the students' perceived service quality for management decision-making. Based on the research findings, the process model of education quality is positively related to the students' perceived service quality. As part of the efforts to improve the students' perceived service quality among the students, administrators are advised to implement various strategies to supplement and enhance the process of delivering quality education to the students. The suggested strategies include: (i) the quality enhancement of the librarians in handling students' enquiries, (2) the encouragement of staff responsiveness from the Division of Examinations and Rewards upon students' requests; (3) maintaining the contemporary and practicality of the curriculum; and (4) increasing the amount of recreational activities provided to the students as part of the efforts to complement quality education.

\subsection{Limitations and Recommendations for Future Research}

Although the research findings provide some new insights to researchers, these findings should be viewed in light of some limitations. The study in this research is based on cross-sectional data that is only able to reveal the net effect of predictor variable towards a particular criterion variable at a specific point in time (Cavana et al., 2001). Due to the inherent limitation of cross-sectional study, the research findings are not able to "explain why the observed patterns are there" (Easterby-Smith, Thorpe and Lowe, 2003, p.p.45). In other words, this research is not able to describe satisfactorily in portraying the observed changes in pattern and the causality of the overall students' perceived service quality. In addition, the restriction of the boundary set in selecting the undergraduate business students in University 'A' as samples in this study resulted the findings not able to be generalized across all private higher education institutions in the country.

Due to the limitations of this research, two recommendations are suggested for further research for the purpose of enhancing the study of the students' perceived service quality. Perception of service quality is the individual psychological judgement of the differences between performance and customer's expectation because perceived service quality is defined as "a global judgment, or attitude, relating to the superiority of the service" (Parasuraman et al., 1988, p.16). Psychological judgement will change over time. Therefore, cross-sectional study may not be able to portray the observed changes in patterns and the causality of the students' perceived service quality (Easterby-Smith et al., 2003). In due respect, longitudinal study, which can capture the temporal 
dynamics of perception change that affect the determinants of the students' perceived service quality, is proposed to be adopted in the future research in order to help researchers to identify the cause and effect relationships among the various constructs (Cavana et al., 2001). Besides, it is recommended to broaden the research setting by incorporating more private higher education institutions and drawing more respondents who are enrolled in various undergraduate degree programmes may be able to enhance the validity and generalization of this research findings.

\section{References}

Asubonteng, A., McCleary, K.J., and Swan, J.E. (1996). SERVQUAL revisited: a critical review of service quality. The Journal of Services Marketing, 10(6), 62-81.

Athiyaman, A. (1997). Linking student satisfaction and service quality perceptions: the case of university education. European Journal of Marketing, 31(7), 528-540.

Bennett, R., Bove, L., Dann, S., Drennan, J., Frazer, 1., Gabbott, M., Hill, R., Lawley, M., Matear, S., Perry, C., Sparks, B., Summers, J., Sweeney, J., Ward, T., and White, L. (2003). Services marketing: a managerial approach. Queensland: John Wiley \& Sons.

Bitner, M.J., Booms, B., and Tetreault, S. (1990). The service encounter: diagnosing favourable and unfavourable incidents. Journal of Marketing, 54(1), 71-84.

Bolton, R.N., and Drew, J.H. (1991). A multistage model of customers' assessment of service quality and value. Journal of Consumer Research, 17(4), 375-384.

Buttle, F. (1996). SERVQUAL: review, critique, research agenda. European Journal of Marketing, 30(1), 8-32.

Cavana, R.Y., Delahaye, B.L., and Sekaran, U. (2001). Applied business research: qualitative and quantitative methods. Queensland: John Wiley \& Sons.

Cheng, Y.C. (2003). Quality assurance in education: internal, interface, and future. Quality Assurance in Education, 11(4), 202-213.

Cheng, Y.C., and Tam, M. (1997). Multi-models of quality in education. Quality Assurance in Education, 5(1), 22-31.

Churchill, G.A., and Brown, T.J. (2004). Basic marketing research, $\left(5^{\text {th }}\right.$ edn), Ohio: South-Western.

Crosby, P.B. (1979). Quality is free, New York: McGraw-Hill.

Cuthbert, P.F. (1996). Managing service quality in HE: is SERVQUAL the answer? Part I. Managing Service Quality, 6(2), 11-16.

Dawes, J., and Rowley, J. (1999). Negative evaluations of service quality - a framework for identification and response. Journal of Marketing Practice: Applied Marketing Science, 5(2), 46-55.

Easterby-Smith, M. Thorpe, R., and Lowe, A. (2003). Management research: an introduction, ( $2^{\text {nd }}$ edn), California: SAGE Publications.

Education Guide Malaysia. (2006). (10 ${ }^{\text {th }}$ edn), Petaling Jaya: Challenger Concept.

Feigenbaum, A.V. (1951). Quality control: principles, practice and administration. New York: McGraw-Hill.

Ford, J.B., Joseph, M., \& Joseph, B. (1999). Importance-performance analysis as a strategic tool for service marketers: the case of service quality perceptions of business students in New Zealand and the USA', The Journal of Services Marketing, 13(2), 171-186.

Garvin, D.A. (1987). Competing on the eight dimensions of quality. Harvard Business Review, 65(6), 101-109.

Gilmore, H.L. (1974). Product conformance. Quality Progress, 7(5).

Gotlieb, J.B., Grewal, D., and Brown, S.W. (1994). Consumer satisfaction and perceived quality: complementary or divergent constructs?. Journal of Applied Psychology, 79(6), 875-885.

Gronroos, C. (1984). A service quality model and its marketing implications. European Journal of Marketing, $18(4), 36-44$.

Hair, J.F. Jr, Babin, B., Money, A.H., and Samouel, P. (2003). Essential of business research methods, United States of America: John Wiley \& Sons.

Hair, J.F. Jr, Black, W.C., Babin, B.J., Anderson, R.E., and Tatham, R.L. (2006). Multivariate data analysis, $\left(6^{\text {th }}\right.$ edn), New Jersey: Pearson Education. 
Hair, J.F., Bush, P.R., and Ortinau, D.J. (2004). Marketing research: within a changing information environment, $\left(2^{\text {nd }}\right.$ edn $)$, New York: McGraw-Hill.

Ham, L., and Hayduk, S. (2003). Gaining competitive advantage in higher education: analyzing the gap between expectations and perceptions of service quality. International Journal of Value-Based Management, 16(3), 223-242.

Hill, F.M. (1995). Managing service quality in higher education: the role of the students as primary consumer. Quality Assurance in Education, 3(3), 10-21.

Hoffman, K.D., and Bateson, J.E.G. (2006). Services marketing: concepts, strategies, \& cases, $\left(3^{\text {rd }}\right.$ edn), Ohio: South-Western.

Jankowicz, A.D. (2005) Business research project, $\left(4^{\text {th }}\right.$ edn), London: Thomson Learning.

Joseph, M., Yakhou, M., and Stone, G. (2005). An educational institution's quest for service quality: customers' perspective. Quality Assurance in Education, 13(1), 66-82.

Juran, J.M., and Godfrey, A.B. (2000). Juran's quality handbook, (5 $5^{\text {th }}$ edn), Singapore: McGraw-Hill.

Kang, G.D., and James, J. (2004). Service quality dimensions: an examination of Gronroos's service quality model. Managing Service Quality, 14(4), 266-277.

LeBlanc, G., and Nguyen, N. (1997). Searching for excellence in business education: an exploratory study of customer impression of service quality. International Journal of Educational Management, 11(2), 72-79.

Lee, H., Lee, Y., and Yoo, D. (2000). The determinants of perceived service quality and its relationship with satisfaction. Journal of Services Marketing, 14(3), 217-231.

Malhotra, N., Hall, J., Shaw, M., and Oppenheim, P. (2006). Marketing research: an applied orientation, ( $3^{\text {rd }}$ edn). New South Wales: Prentice Hall.

Marzo-Navarro, M., Pedraja-Iglesias, M., and Rivera-Torres, M.P. (2005). Measuring customer satisfaction in summer courses. Quality Assurance in Education, 13(1), 53-65.

Mazzarol, T. (1998). Critical success factors for international education marketing. The International Journal of Educational Management, 12(4), 163-175.

Ministry of Higher Education, Malaysia. (2006). [Online] Available: http://www.mohe.gov.my. (April 24, 2006)

Nagata, H., Satoh, Y., Gerrard, S., and Kytomaki, P. (2004). The dimensions that construct the evaluation of service quality in academic libraries. Performance Measurement and Metrics, 5(2), 53-65.

Parasuraman, A., Zeithaml, V.A., and Berry, L.L. (1985). A conceptual model of service quality and its implications for future research. Journal of Marketing, 49(4), Autumn, 41-50.

Parasuraman, A., Zeithaml, V.A., and Berry, L.L. (1988). SERVQUAL: a multiple-item scale for measuring consumer perceptions of service quality. Journal of Retailing, 64(1), Spring, 12-40.

Pariseau, S.E., and McDaniel, J.R. (1997). Assessing service quality in schools of business. The International Journal of Quality \& Reliability Management, 14(3), 204-235.

Peters, T.J., and Waterman, R.H. (1982). In search of excellent, New York: Harper \& Row.

Philip, G., and Hazlett, S-A. (1997). The measurement of service quality: a new P-C-P attributes model. International Journal of Quality \& Reliability Management, 14(3), 260-286.

Pounder, J. (1999). Institutional performance in higher education: is quality a relevant concept. Quality Assurance in Education, 7(3), 14-22.

Reeves, C.A., and Bednar, D.A. (1994). Defining quality: alternatives and implications. Academy of Management Review, 19(3), 419-445.

Reichheld, F.F., and Sasser, W.E. Jr. (1990). Zero defections: quality comes to service. Harvard Business Review, 68(5), 105-111.

Russell, M. (2005). Marketing education: a review of service quality perceptions among international students. International Journal of Contemporary Hospitality Management, 17(1), 65-77.

Ruyter, K.D., Bloemer, J., and Peeters, P. (1997). Merging service quality and service satisfaction: an empirical test of an integrative model. Journal of Economic Psychology, 18, 387-406. 
Sahney, S., Banwet, D.K., and Karunes, S. (2004). Conceptualizing total quality management in higher education. The TQM Magazine, 16(2), 145-159.

Sander, P., Stevenson, K., King, M., and Coates, D. (2000). University student's expectations of teaching. Studies in Higher Education, 25(3), 309-329.

Sekaran, U. (2003). Research methods for business: A skill building approach. New Jersey: John Wiley \& Sons.

Sohail, M.S., and Shaikh, N.M. (2004). Quest for excellent in business education: a study of student impressions of service quality. The International Journal of Educational Management, 18(1), 58-65.

Soutar, G., and McNell, M. (1996). Measuring service quality in a tertiary institution. Journal of Educational Administration, 34(1), 72-82.

Tam, W.M., and Cheng, Y.C. (1996). Staff development for school education quality: implications of multimodels. Training for Quality, 4(4), 16-24.

Table 1. Five Factors Identified by the Principal Components Factor Analysis

\begin{tabular}{|c|c|c|c|c|c|}
\hline $\begin{array}{l}\text { Factor's } \\
\text { Name }\end{array}$ & Variable & $\begin{array}{l}\text { Factor } \\
\text { Loading }\end{array}$ & $\begin{array}{l}\text { Eigen- } \\
\text { value }\end{array}$ & $\begin{array}{c}\text { Percentage } \\
\text { of Variance } \\
\text { Explained }\end{array}$ & $\begin{array}{l}\text { Cronbach's } \\
\text { Reliability } \\
\text { Coefficients }\end{array}$ \\
\hline $\begin{array}{l}\text { Quality of } \\
\text { Librarians }\end{array}$ & $\begin{array}{l}\text { Ready to respond to student's } \\
\text { questions } \\
\text { Competent to answer student's } \\
\text { questions } \\
\text { Provide service reliably, consistently, } \\
\text { and dependably } \\
\text { Deal with students in a concerned or } \\
\text { considerate fashion } \\
\text { Make the effort to understand the } \\
\text { needs of the students }\end{array}$ & $\begin{array}{l}0.904 \\
0.897 \\
0.885 \\
0.845 \\
0.807\end{array}$ & 7.031 & 21.022 & 0.932 \\
\hline $\begin{array}{l}\text { Amount of } \\
\text { Recreational } \\
\text { Activities }\end{array}$ & $\begin{array}{l}\text { Student organizations are offered as } \\
\text { extra-curricular activities } \\
\text { Extra-curricular activities are offered } \\
\text { to students } \\
\text { Sports teams for entertainment are } \\
\text { offered to students } \\
\text { Opportunities to participate in a variety } \\
\text { of sports } \\
\text { Recreational facilities and programmes } \\
\text { are offered to students }\end{array}$ & $\begin{array}{l}0.863 \\
0.847 \\
0.847 \\
0.769 \\
0.733\end{array}$ & 2.968 & 18.917 & 0.893 \\
\hline Curriculum & $\begin{array}{l}\text { The number of courses offered } \\
\text { Suitability of the academic } \\
\text { programmes and course content } \\
\text { Objectives of the academic } \\
\text { programmes are explained to the } \\
\text { students }\end{array}$ & $\begin{array}{l}0.851 \\
0.837 \\
0.773\end{array}$ & 1.431 & 12.412 & 0.857 \\
\hline $\begin{array}{l}\text { Staff } \\
\text { Responsive-n } \\
\text { ess from the } \\
\text { Division of } \\
\text { Examinations } \\
\text { \& Awards }\end{array}$ & $\begin{array}{l}\text { Examination registration is timely and } \\
\text { error-free } \\
\text { Examination records are kept } \\
\text { accurately } \\
\text { Students are informed promptly of any } \\
\text { changes }\end{array}$ & $\begin{array}{l}0.858 \\
0.822 \\
0.743\end{array}$ & 1.155 & 11.922 & 0.841 \\
\hline $\begin{array}{l}\text { Students' } \\
\text { perceived } \\
\text { service } \\
\text { quality }\end{array}$ & $\begin{array}{l}\text { Students' perceived S.Q.3 } \\
\text { Students' perceived S.Q.2 } \\
\text { Students' perceived S.Q.1 }\end{array}$ & $\begin{array}{l}0.861 \\
0.836 \\
0.831\end{array}$ & 2.029 & 12.642 & 0.890 \\
\hline
\end{tabular}

KMO Measure of Sampling Adequacy $=0.878 ; \mathrm{p}=0.000(\mathrm{p}<0.05) ; \mathrm{df}=171$

Cumulative Percentage Rotation Sums of Squared Loadings $=76.914$ 
Table 2. Result of Multiple Linear Regression Analysis for this Research

\begin{tabular}{|c|c|c|c|c|c|c|}
\hline & \multirow{2}{*}{ Model } & \multicolumn{2}{|c|}{$\begin{array}{c}\text { Unstandardized } \\
\text { Coefficients } \\
\end{array}$} & \multirow{2}{*}{$\begin{array}{c}\text { Standardized } \\
\text { Coefficients }\end{array}$} & \multirow[t]{2}{*}{$\mathbf{t}$} & \multirow[t]{2}{*}{ Sig. } \\
\hline & & B & Std. Error & & & \\
\hline \multirow[t]{8}{*}{1} & (Constant) & 2.683 & 0.666 & & 4.030 & 0.000 \\
\hline & Quality of Librarians & 0.112 & 0.024 & 0.196 & 4.707 & 0.000 \\
\hline & Staff Responsiveness & & & & & \\
\hline & $\begin{array}{l}\text { from the Division of } \\
\text { Examinations \& }\end{array}$ & 0.211 & 0.050 & 0.197 & 4.190 & 0.000 \\
\hline & Awards & & & & & \\
\hline & Curriculum & 0.213 & 0.050 & 0.198 & 4.233 & 0.000 \\
\hline & Amount of & & & & & \\
\hline & $\begin{array}{l}\text { Recreational } \\
\text { Activities }\end{array}$ & 0.107 & 0.024 & 0.193 & 4.443 & 0.000 \\
\hline
\end{tabular}

a Dependent Variable: Students' Perceived Service Quality

Independent variables: quality of librarians, staff responsiveness from the Division of Examinations \& Awards, curriculum and the amount of recreational activities.

$\mathrm{R}=55.6$ per cent; $\quad \mathrm{R}$ Square $=30.9$ per cent $; \quad$ Adjusted $\mathrm{R}$ Square $=30.3$ per cent;

$\mathrm{F}=50.731 ; \quad \mathrm{P}=0.000(\mathrm{p}<0.05)$

Table 3. Result of Simple Linear Regression Analysis for this Research

\begin{tabular}{|c|c|c|c|c|c|c|}
\hline \multicolumn{2}{|c|}{ Model } & \multicolumn{2}{|c|}{$\begin{array}{c}\text { Unstandardized } \\
\text { Coefficients }\end{array}$} & $\begin{array}{c}\text { Standardized } \\
\text { Coefficients }\end{array}$ & \multirow{2}{*}{ t } & \multirow{2}{*}{ Sig. } \\
\cline { 3 - 6 } & B & Std. Error & Beta & & \\
\hline 1 & $\begin{array}{c}\text { (Constant) } \\
\text { Process Model of } \\
\text { Education Quality }\end{array}$ & 3.224 & 0.635 & & 5.075 & 0.000 \\
& 0.142 & 0.010 & 0.546 & 13.917 & 0.000 \\
\hline
\end{tabular}

a Dependent Variable: Students' Perceived Service Quality

Independent variables: Process Model of Education Quality

Note: Process model of education quality composes of quality of librarians, staff responsiveness from the Division of Examinations \& Awards, curriculum and the amount of recreational activities.

$\mathrm{R}=54.6$ per cent; $\quad \mathrm{R}$ Square $=29.8$ per cent; Adjusted $\mathrm{R}$ Square $=29.7$ per cent;

Composite Reliability $=0.603 \mathrm{~F}=193.678 ; \quad \mathrm{P}=0.000(\mathrm{p}<0.05)$ 